\title{
Marketing Pattern of Pig Farmers in Dima Hasao District of Assam, India
}

\author{
Monosri Johari $^{1 *}$, Pulin Hazarika ${ }^{1}$, Manindra Nath Ray ${ }^{1}$, Leema Bora ${ }^{1}$, \\ Sadananda Payeng ${ }^{1}$, Koushik Kakoty ${ }^{2}$ and Keshab Jamatia ${ }^{1}$ \\ ${ }^{1}$ Department of Extension Education, CVSc.AAU Khanapara, India \\ ${ }^{2}$ Department of Veterinary Public Health, LCVSc. Joyhing, India \\ *Corresponding author
}

\begin{abstract}
A B S T R A C T
Pig farming is a household traditional activity in the hill district of Assam. 100 pig farmers were purposively selected from two blocks namely Jatinga Valley Development Block and Diyungbra ITDP Block for the present study. Structured interview schedule was used for data collection after pretesting and validation of the schedule. Majority of the pig farmers $(82.00 \%)$ of the respondents belonged to medium category of distribution in place/person to whom pig was sold in Block all categories (i.e. Block I, Block II and Pooled sample). It was also revealed that 70 per cent, 84 per cent and 83 per cent were in medium category in the area of mode of marketing in Block I, Block II and pooled sample respectively. When specifically studied, it was revealed that a large proportion of 96 per cent, 70 per cent and 83 per cent of the respondents sold their pigs when pig was around one year in Block I, Block II and pooled sample respectively. In case of mode of marketing it was found that 70 per cent, 36 per cent and 53 per cent of the respondents' preferred selling to vendors in Block I, Block II and pooled sample respectively and in Block II 78 per cent preferred selling live sale at farm. There was significant difference between the respondents of the two block ( $\mathrm{t}=5.38, \mathrm{P}<0.01)$ with regard to place/ person to whom pig was sold. There was also significant difference between the respondents of the two block $(\mathrm{t}=4.82, \mathrm{P}<0.01)$ with regard to mode of marketing.
\end{abstract}

\section{Introduction}

Market is a place where buyers and sellers meet at common place for exchange of their goods and services. According to Dixon et al., (2001), markets are usually poorly developed or are missing in developing countries. Rural markets in LDCs, in particular, are fraught with weakness. Transaction costs are often high because of the inherent problematic conditions in many rural area such as roads, bridges are poorly developed; lack of communication, transportation facilities. Therefore trading of livestock and livestock product are unfavourable for the farmers. It is seen that those resorting to better rearing and smart marketing are reaping more benefits than others. Further at times the benefits are reaped by people other than the actual rearers due to some risks they might be resorting to or avoiding. Therefore, a study was conducted to find out the marketing pattern of the pig 
rearers in that difficult Dima Hasao district of Assam.

\section{Materials and Methods}

The study was undertaken in two selected blocks of Dima Hasao (the erstwhile North Cachar) district of Assam during the month of January to March 2018. 100 pig farmers were purposively selected from two blocks namely Jatinga Valley Development Block and Diyungbra ITDP Block for the present study. Two villages were selected purposively from each block. From each selected village 25 farmers were interviewed for the study, thus making 50 sample per block. Structured interview schedule was used for data collection after pretesting and validation of the schedule. For obtaining response on different component areas of place/person to whom pig was sold, the respondents were offered nine statements and they were asked to respond in either of the three degrees ranging from mostly, sometimes and rarely categories. The scores were 3 for mostly, 2 for sometimes and 1 for rarely respectively. As such the minimum and maximum obtainable scores for a respondent were 9 and 27 respectively. In case of mode of marketing, the respondents were offered six statements and they were asked to respond in either of the three degrees ranging from mostly, sometimes and rarely categories. The scores were 3 for mostly, 2 for sometimes and 1 for rarely respectively. Thus 6 and 18 were minimum and maximum obtainable scores for a respondent respectively. The interview schedule was pre-tested for the reliability and validity of the schedule. The worked out reliability coefficient was 0.93 and content validation was ensured by consulting the experts and faculties serving in the field and the University respectively.

\section{Results and Discussion}

Marketing is the guiding force and short run incentive for farm produces and in turn whole farming system. It is the sum total of economic activities, which are undertaken to help the movement of the produce from the point of the production to the point of consumption. Table 1 showed that 82 per cent of the respondents belonged to medium category of distribution in place/person to whom pig was sold in Block all categories (i.e. Block I, Block II and Pooled sample). The same table revealed that 70 per cent, 84 per cent and 83 per cent were in medium category in the area of mode of marketing in Block I, Block II and pooled sample respectively.

Table.1 Frequency distribution of the respondents on the basis of their marketing

\begin{tabular}{|c|c|c|c|c|c|c|c|c|}
\hline Variables & Blocks & Mean & SD & Range & Low & Medium & High & 't' value \\
\hline \multirow[t]{3}{*}{$\begin{array}{l}\text { Place/person to } \\
\text { whom sold }\end{array}$} & Block I & 16.00 & 2.82 & $\begin{array}{l}8.62- \\
20.40\end{array}$ & $5(10)$ & $41(82)$ & $4(8)$ & \multirow[t]{3}{*}{$5.38 * *$} \\
\hline & Block II & 13.67 & 2.48 & $\begin{array}{l}9.33- \\
16.20\end{array}$ & $9(18)$ & $41(82)$ & $0(0)$ & \\
\hline & Pooled & 14.8405 & 2.89 & $\begin{array}{l}8.62- \\
20.40\end{array}$ & $13(13)$ & $82(82)$ & $4(4)$ & \\
\hline \multirow{3}{*}{$\begin{array}{l}\text { Mode of } \\
\text { marketing }\end{array}$} & Block I & 10.35 & 2.11 & $6-14$ & $6(12)$ & $35(70)$ & $9(18)$ & \multirow{3}{*}{ 4. $82 * *$} \\
\hline & Block II & 8.58 & 1.77 & $5.66-12$ & $3(6)$ & $42(84)$ & $5(10)$ & \\
\hline & Pooled & 9.4733 & 2.13 & $5.66-14$ & $9(9)$ & $83(83)$ & $8(8)$ & \\
\hline
\end{tabular}

Figures in the parenthesis indicate percentage 
Table.2 Frequency distribution of respondents on the basis of person to whom pig was sold

\begin{tabular}{|c|c|c|c|c|c|}
\hline \multirow{2}{*}{$\begin{array}{l}\text { SI. } \\
\text { No }\end{array}$} & \multirow{2}{*}{$\begin{array}{c}\text { Place /Person to whom } \\
\text { sold }\end{array}$} & \multirow[t]{2}{*}{ Blocks } & \multicolumn{3}{|c|}{ Degree of information } \\
\hline & & & Mostly & Sometimes & Rarely \\
\hline \multirow[t]{3}{*}{1.} & \multirow[t]{3}{*}{ Directly to consumer } & Block I & 2(4) & $0(0)$ & $0(0)$ \\
\hline & & Block II & $14(28)$ & $1(2)$ & $0(0)$ \\
\hline & & Pooled & $16(16)$ & $1(1)$ & $0(0)$ \\
\hline \multirow[t]{3}{*}{2.} & \multirow[t]{3}{*}{ To wholesaler } & Block I & $39(78)$ & $0(0)$ & $0(0)$ \\
\hline & & Block II & $2(4)$ & $3(6)$ & $0(0)$ \\
\hline & & Pooled & $41(41)$ & $3(3)$ & $0(0)$ \\
\hline \multirow[t]{3}{*}{3.} & \multirow[t]{3}{*}{ To vendors } & Block I & $11(22)$ & $4(8)$ & $0(0)$ \\
\hline & & Block II & $34(68)$ & $11(22)$ & $0(0)$ \\
\hline & & Pooled & $45(45)$ & $15(15)$ & $0(0)$ \\
\hline \multirow[t]{3}{*}{4.} & \multirow[t]{3}{*}{ On demand } & Block I & $7(14)$ & $13(26)$ & $2(4)$ \\
\hline & & Block II & $0(0)$ & $0(0)$ & $1(2)$ \\
\hline & & Pooled & $7(7)$ & 13(13) & $3(3)$ \\
\hline \multirow[t]{3}{*}{5.} & \multirow[t]{3}{*}{ When price is more } & Block I & $1(2)$ & $6(12)$ & $3(6)$ \\
\hline & & Block II & $0(0)$ & $0(0)$ & $0(0)$ \\
\hline & & Pooled & $1(1)$ & $6(6)$ & $3(3)$ \\
\hline \multirow[t]{3}{*}{6.} & \multirow{3}{*}{$\begin{array}{l}\text { When age is around one } \\
\text { year }\end{array}$} & Block I & $48(96)$ & 1(2) & $0(0)$ \\
\hline & & Block II & $35(70)$ & $0(0)$ & $0(0)$ \\
\hline & & Pooled & $83(83)$ & 1(1) & $0(0)$ \\
\hline \multirow[t]{3}{*}{7.} & \multirow[t]{3}{*}{ During festival } & Block I & $21(42)$ & $22(44)$ & $6(12)$ \\
\hline & & Block II & $0(0)$ & $35(70)$ & $14(28)$ \\
\hline & & Pooled & $21(21)$ & $57(57)$ & $20(20)$ \\
\hline \multirow[t]{3}{*}{8.} & \multirow{3}{*}{$\begin{array}{l}\text { At the time of important } \\
\text { domestic occasion }\end{array}$} & Block I & $21(42)$ & $23(46)$ & $6(12)$ \\
\hline & & Block II & 1(2) & $29(58)$ & $20(40)$ \\
\hline & & Pooled & $23(23)$ & $52(52)$ & $26(26)$ \\
\hline \multirow[t]{3}{*}{9.} & \multirow{3}{*}{$\begin{array}{l}\text { Social } \\
\text { occasions/celebration }\end{array}$} & Block I & $20(40)$ & $24(48)$ & $6(12)$ \\
\hline & & Block II & 2(4) & $30(60)$ & $12(24)$ \\
\hline & & Pooled & $22(22)$ & $54(54)$ & $18(18)$ \\
\hline
\end{tabular}

Figures in the parenthesis indicate percentage. 
Table.3 Frequency distribution of respondents on the basis of their mode of marketing

\begin{tabular}{|c|c|c|c|c|c|}
\hline \multirow{2}{*}{$\begin{array}{l}\text { SI. } \\
\text { No }\end{array}$} & \multirow{2}{*}{$\begin{array}{l}\text { Mode of marketing giving } \\
\text { more benefits }\end{array}$} & \multirow[t]{2}{*}{ Blocks } & \multicolumn{3}{|c|}{ Degree of information } \\
\hline & & & Mostly & Sometimes & Rarely \\
\hline \multirow[t]{3}{*}{1.} & \multirow[t]{3}{*}{ Live sale at farm } & Block I & $0(0)$ & $0(0)$ & $0(0)$ \\
\hline & & Block II & $39(78)$ & $1(2)$ & $0(0)$ \\
\hline & & Pooled & $39(39)$ & $1(1)$ & $0(0)$ \\
\hline \multirow[t]{3}{*}{2.} & \multirow{3}{*}{$\begin{array}{l}\text { Slaughtered locally } \\
\text { when pig matures }\end{array}$} & Block I & $3(6)$ & $4(8)$ & $14(28)$ \\
\hline & & Block II & $0(0)$ & $6(12)$ & $19(38)$ \\
\hline & & Pooled & $3(3)$ & $10(10)$ & $33(33)$ \\
\hline \multirow[t]{3}{*}{3.} & \multirow{3}{*}{$\begin{array}{l}\text { Slaughtered locally on } \\
\text { demand }\end{array}$} & Block I & $14(28)$ & $19(38)$ & $6(12)$ \\
\hline & & Block II & $3(6)$ & $13(26)$ & $11(22)$ \\
\hline & & Pooled & $17(17)$ & $32(32)$ & $17(17)$ \\
\hline \multirow[t]{3}{*}{4.} & \multirow[t]{3}{*}{ Selling to marketers } & Block I & $0(0)$ & $10(20)$ & $17(34)$ \\
\hline & & Block II & $2(4)$ & $9(18)$ & $3(6)$ \\
\hline & & Pooled & $2(2)$ & 19(19) & $20(20)$ \\
\hline \multirow[t]{3}{*}{5.} & \multirow[t]{3}{*}{ Selling to vendors } & Block I & $35(70)$ & $8(16)$ & $4(8)$ \\
\hline & & Block II & $18(36)$ & $19(38)$ & $3(6)$ \\
\hline & & Pooled & $53(53)$ & $27(27)$ & $7(7)$ \\
\hline \multirow[t]{3}{*}{6.} & \multirow[t]{3}{*}{ Acute need of money } & Block I & $0(0)$ & $8(16)$ & $1(2)$ \\
\hline & & Block II & $0(0)$ & $0(0)$ & $0(0)$ \\
\hline & & Pooled & $0(0)$ & $8(8)$ & $1(1)$ \\
\hline
\end{tabular}

Figures in the parenthesis indicate percentage

As the tribal people in Dima Hasao took and followed pig rearing as a means of traditional and household activity, the aggressiveness in endeavor was missing; this kept the rearers in middle group of frequency distribution in marketing profiles. It could be seen from Table 2 that 96 per cent, 70 per cent and 83 per cent of the respondents sold their pigs when pig was around one year in Block I, Block II and pooled sample respectively. Because, the quality of pork they obtained at that age of the pig was treated as the best by the customers/consumers.

However, as was observed at the time of data collection by the researcher, this was because of the demand of replacement rather than any economic gain or loss. This was in line with the findings of Rahman et al., (2008) who reported that in Aizawl pigs were marketed at the age of 1 year or more when they reached body weight of $90 \mathrm{~kg}$ or more due to back fat thickness which is preferred more by the consumers.

It could be seen from Table 3 that 70 per cent, 36 per cent and 53 per cent of the respondents' preferred selling to vendors in Block I, Block II and pooled sample respectively and in Block II 78 per cent preferred selling live sale at farm. This was mainly to avoid killing the pigs by themselves. Deka et al., (2007) found that due to difficulties in transporting slaughtered pigs to market, producers preferred to sell at the farm gate to pork retailers and Knipps (2004) and Payeng et. al. (2017) reported that the village pig keepers sell their pigs either to traders, slaughterers or directly to consumers. Table 1 showed that there was significant difference between the respondents of the two block $(\mathrm{t}=5.38, \mathrm{P}<0.01)$ with regard to place/ 
person to whom pig was sold. It was further observed that the mean score of Block I was more in comparison to Block II. Since mode of marketing in case of Block I was more in comparison to Block II. Table 1 showed that there was significant difference between the respondents of the two block $(\mathrm{t}=4.82, \mathrm{P}<$ 0.01 ) with regard to mode of marketing. This variation was due to the options open in terms of place/person to whom pig was sold in case of Block I was more in comparison to Block II.

\section{Acknowledgement}

We are thankful to Head, Department of Extension Education, CVSc. AAU, Khanapara for successful conduction of our research and also thankful to veterinary department of Dima Hasao district for their cooperation in providing secondary data.

\section{References}

Deka, R.., Thorpe, W., Lapar, M.L. and Kumar, A. 2007. Assam's pig subsector: current status, constraints and opportunities. Project report, Markets theme, International Livestock Research Institute, Nairobi, Kenya.

Dixon, J., Gulliver, A. and Gibbon, D. 2001. Farming Systems and Poverty: Improving Farmers' Livelihood in a changing World, FAO and World Bank, Rome and Washington, DC.

Knipps, V. 2004. Cambodia, Lao PDR, Thailand, Vietnam :Review of the Livestock Sector in the Mekong Countries" Livestock Information, Sector Analysis and Policy Branch. AGAL, FAO

Rahman, S., Barthakur, S. and Kalita, G. 2008. Pig production and management system in Aizawl District of Mizoram, India. Livestock Research for Rural Development, 20(9): Article\# 139.

Payeng, S., Borgohain, A., Ray, M.N. and Bora, J.R. 2017 Marketing Pattern of Pig and Pork of Organized and Unorganized Pig Farmers in Kamrup District of Assam Indian Journal of Social Research Vol.58 (5) 715-719

\section{How to cite this article:}

Monosri Johari, Pulin Hazarika, Manindra Nath Ray, Leema Bora, Sadananda Payeng, Koushik Kakoty and Keshab Jamatia. 2020. Marketing Pattern of Pig Farmers in Dima Hasao District of Assam, India. Int.J.Curr.Microbiol.App.Sci. 9(04): 599-603. doi: https://doi.org/10.20546/ijcmas.2020.904.073 